\title{
The methods of synthetic assessment of emissions from combustion engines
}

\begin{abstract}
The paper discusses the possibilities of a synthetic assessment of a harmful impact of combustion engine emissions on humans and their natural environment. The ways of air quality evaluations have been analyzed. The authors analyzed the relations of emission charges for combustion engines as per the proposal of the directive of the European Parliament and the European Council in line with the Announcement of the Minister of Environment. A synthetic assessment of the emissions from combustion engines has been proposed. The method of emission assessment was used for the research on the ecological properties of a classic EURO IV diesel engine and a diesel engine fuelled with E95 bioethanol fuel.
\end{abstract}

Key words: combustion engines, toxic emissions, air pollution

\section{O metodach syntetycznej oceny emisji zanieczyszczeń z silników spalinowych}

\begin{abstract}
W artykule rozpatrzono możliwość syntetycznej oceny szkodliwości dla ludzi i ich środowiska substancji emitowanych przez silniki spalinowe. Przeanalizowano sposoby oceny jakości powietrza. Oceniono relacje opłat za zanieczyszczenia emitowane przez silniki spalinowe zgodnie z propozycja Dyrektywy Parlamentu Europejskiego i Rady oraz zgodnie z Obwieszczeniem Ministra Środowiska. Zaproponowano syntetyczna ocenę emisji zanieczyszczeń z silników spalinowych. Metodę oceny emisji zanieczyszczeń wykorzystano do badania właściwości ekologicznych klasycznego silnika o zapłonie samoczynnym kategorii ekologicznej EURO IV i silnika o zapłonie samoczynnym zasilanego paliwem bioetanolowym E95.

Słowa kluczowe: silniki spalinowe, emisja zanieczyszczeń, zanieczyszczenia powietrza
\end{abstract}

\section{Introduction}

Emissions harmful for mankind and its environment are one of the greatest threats related to the use of combustion engines. These threats related to the toxic emissions can be classified as [3-5, 9]:

- local,

- global,

- complex.

Local threats are caused by the emissions of substances harmful for humans and other living organisms [1, 3-5]. Particularly dangerous toxic emissions from the combustion engines are as follows $[3-5,8]$ :

- carbon monoxide,

- organic compounds, particularly heavy organic compounds,

- nitric oxides, particularly $\mathrm{NO}$ and $\mathrm{NO}_{2}$,

- particulate matter, constituting the PM10 (aerodynamic diameter lower than $10 \mu \mathrm{m}$ ) and fine PM2.5 (aerodynamic diameter lower than $2.5 \mu \mathrm{m}$ ).

The emission of sulfur and lead compounds is as yet not a significant ecological problem in the automotive industry due to a drastic reduction of their application in the engine fuels $[3-5,8]$.

The largest global threat related to the operation of combustion engines is the emission of carbon dioxide which is the most significant component of the exhaust gases facilitating the greenhouse effect - significant not only due to its greenhouse effect related potential but also due to the scale of its emission in comparison to other toxic emissions [3-5, 9, 14].

Out of the complex threats a particularly dangerous for the lives of humans and their environment is the emission of

\section{Wprowadzenie}

Emisja zanieczyszczeń szkodliwych dla ludzi i ich środowiska należy do największych zagrożeń związanych z eksploatacją silników spalinowych. Zagrożenia spowodowane emisją zanieczyszczeń z silników spalinowych można sklasyfikować jako [3-5, 9]:

- lokalne,

- globalne,

- złożone.

Zagrożenia lokalne są spowodowane emisją substancji szkodliwych dla zdrowia ludzi i innych organizmów żywych [1, 3-5]. Do szczególnie groźnych zanieczyszczeń, pochodzących z silników spalinowych, zalicza się $[3-5,8]$ :

- tlenek węgla,

- związki organiczne, szczególnie ciężkie związki organiczne,

- tlenki azotu, głównie tlenek azotu i dwutlenek azotu,

- cząstki stałe, będące składnikami pyłu zawieszonego PM10 (o średnicy aerodynamicznej mniejszej niż 10 $\mu \mathrm{m}$ ) i pyłu drobnego PM2,5 (o średnicy aerodynamicznej mniejszej niż 2,5 $\mu \mathrm{m}$ ).

Emisja związków siarki i ołowiu nie jest obecnie znaczącym problemem ekologicznym motoryzacji dzięki radykalnemu ograniczeniu udziału tych pierwiastków w paliwach silnikowych [3-5, 8].

Największym zagrożeniem globalnym związanym z eksploatacją silników spalinowych jest emisja dwutlenku węgla, który jest najbardziej znaczącym składnikiem spalin, sprzyjającym intensyfikacji zjawiska cieplarnianego w atmosferze - nie tylko z powodu potencjału tego związku do sprzyjania zjawisku cieplarnianemu, ale przede wszystkim z 
tropospheric ozone facilitating the formation of photospheric smog $[2-5,9]$. The basic precursors of tropospheric ozone are volatile organic compounds and nitric oxides [2] hence, substances the emission of which comes mainly from the combustion engines [3-5].

The impact of the combustion engines on the environment is based on the evaluation of the quantities characterizing the emissions as opposed to the limits set forth in legislative acts $[3,4,8]$. The quantities characterizing the emission from combustion engines for the evaluation of their environmental impact are:

- road emissions which are a derivative of the mass versus the distance covered by the vehicle; road emissions are used for the evaluation of combustion engines used only in vehicles-passenger vehicles in particular and light duty vehicles $[3,4]$,

- unit emissions which are a derivative of the emissions versus usable engine work; unit emissions are used for engines of a variety of applications i.e. heavy duty vehicle engines (trucks and buses) and other heavy machinery [3, 4].

The road emissions in homologation tests are determined as a mean value during the road tests realized on a chassis dynamometer [3, 4, 8]. In the European Union and non-EU member states being the signatories of the 1958 Geneva Agreement where the UN ECE regulations apply, the current road emission limits are ${ }^{1)}$ Euro I-Euro IV (in the future Euro $\mathrm{V}$ and Euro VI) pertaining to $[3,4,8]$ :

- carbon monoxide $\mathrm{CO}$,

- hydrocarbons $\mathrm{HC}$,

- nitric oxides $\mathrm{NO}_{x}$ : nitrogen monoxide $\mathrm{NO}$ nitrogen dioxide $\mathrm{NO}_{2}$, reduced to nitrogen oxide,

- particulate matter PM (for diesel engines).

The homologation driving cycle in the European Union is compliant with the regulation $83 \operatorname{EEC}[3,4,8]$. This test is composed of the UDC (Urban Driving Cycle) simulating urban driving and EUDC (Extra Urban Driving Cycle) simulating extra urban driving $[3,4,8]$.

Unit emissions in the homologation tests are determined as a mean value in the tests realized on a engine test bed. As per regulation $49 \mathrm{EEC}$ current unit emission limits are marked Euro II-Euro IV (in the future Euro V and Euro VI) $[3,4,8]$. The Euro III measurements are performed in tests $[3,4,8]$ :

- stationary ESC (European Stationary Cycle) $)^{2}$ - for diesel engines,

\footnotetext{
${ }^{1)}$ According to the EU legislation the emission tests on a chassis dynamometer are performed for vehicles of the $M_{1}$ (passenger vehicles) and $N_{1}$ (light duty trucks of GVW lower than $3.5 \mathrm{Mg}$ ) categories - the road limits of emission are marked EURO (or Euro) with subsequent digits following. The engine test bed serves for the testing of emissions from vehicle engines of the $\mathrm{M}_{2}, \mathrm{M}_{3}, \mathrm{~N}_{2}$ and $\mathrm{N}_{3}$ categories i.e. engines from vehicles of GVW exceeding $3.5 \mathrm{Mg}$ : diesel and spark ignition fueled with gaseous fuels: NG - natural gas and LPG - liquefied petroleum gas - the unit emission limits are marked EURO (or Euro) with subsequent digits following [8].

2) In some publications we encounter the term ESC - European Stationary Cycle, resulting from a general lack of understanding of the notion stationary erroneously described in the Polish language as stationary instead of static.
}

powodu skali emisji w stosunku do emisji innych substancji [3-5, 9, 14].

Spośród zagrożeń złożonych szczególnie niebezpieczna dla zdrowia ludzi i ich środowiska jest emisja ozonu troposferycznego, sprzyjającego powstawaniu smogu fotochemicznego [2-5, 9]. Podstawowymi prekursorami ozonu troposferycznego są lotne związki organiczne i tlenki azotu [2], a zatem substancje, których emisja pochodzi głównie ze spalin silników [3-5].

Szkodliwość silników spalinowych dla środowiska ocenia się przede wszystkim na podstawie wielkości charakteryzujących emisję zanieczyszczeń, w stosunku do limitów tych wielkości ustanowionych przez akty prawne [3, 4, 8]. Wielkościami charakteryzującymi emisję zanieczyszczeń z silników spalinowych do oceny ich jakości ekologicznej są:

- emisja drogowa zanieczyszczeń, która jest pochodna emisji zanieczyszczeń będącej ich masą, względem drogi przebywanej przez pojazd; emisję drogową wykorzystuje się do oceny silników spalinowych stosowanych tylko do pojazdów, a przede wszystkim do silników samochodów osobowych i lekkich samochodów ciężarowych [3, 4],

- emisja jednostkowa zanieczyszczeń, będąca pochodną emisji zanieczyszczeń względem pracy użytecznej silnika spalinowego; emisję jednostkową używa się do oceny silników spalinowych o różnych zastosowaniach, m.in. ciężkich silników spalinowych do samochodów ciężarowych i autobusów, a jednocześnie innych maszyn $[3,4]$.

Emisję drogową w badaniach homologacyjnych wyznacza się jako wartość średnią w testach jezdnych, realizowanych na hamowni podwoziowej $[3,4,8]$. W Unii Europejskiej oraz w państwach europejskich niebędących członkami Unii, ale będących sygnatariuszami Porozumienia Genewskiego z 1958 r., w których obowiązują regulaminy Europejskiej Komisji Gospodarczej ONZ (UN ECE), obecne limity emisji drogowej zanieczyszczeń są oznaczane ${ }^{1)}$ Euro I-Euro IV (a w przyszłości Euro V i Euro VI) i dotyczą [3, 4, 8]:

- tlenku węgla $\mathrm{CO}$,

- węglowodorów $\mathrm{HC}$,

- tlenków azotu $\mathrm{NO}_{\mathrm{x}}$ : tlenku azotu NO i dwutlenku azotu $\mathrm{NO}_{2}$, sprowadzonych do tlenku azotu,

- cząstek stałych PM (dla silników o zapłonie samoczynnym).

Homologacyjny test jezdny w Unii Europejskiej jest zgodny z regulaminem nr 83 EKG $[3,4,8]$. Test ten składa

\footnotetext{
1) Zgodnie z prawodawstwem Unii Europejskiej badania emisji zanieczyszczeń na hamowni podwoziowej przeprowadza się dla pojazdów samochodowych kategorii $\mathrm{M}_{1}$ (samochody osobowe) i $\mathrm{N}_{1}$ (lekkie samochody ciężarowe o dopuszczalnej masie całkowitej mniejszej niż 3,5 Mg)-limity emisji drogowej zanieczyszczeń są tradycyjnie oznaczane EURO (lub Euro) oraz kolejnymi liczbami pisanymi cyframi arabskimi. Na hamowni silnikowej bada się emisję zanieczyszczeń z silników pojazdów samochodowych kategorii $\mathrm{M}_{2}, \mathrm{M}_{3}, \mathrm{~N}_{2}$ i $\mathrm{N}_{3}$, czyli z silników do pojazdów o dopuszczalnej masie całkowitej większej niż 3,5 Mg: o zapłonie samoczynnym i o zapłonie iskrowym na paliwa gazowe: gaz ziemny (NG - natural gas) i skroplony gaz ropopochodny (LPG - liquefied petroleum gas) - limi-ty emisji jednostkowej zanieczyszczeń są tradycyjnie oznaczane EURO (lub Euro) oraz kolejnymi liczbami pisanymi cyframi rzymskimi [8].
} 
- transient/dynamic ETC (European Transient Cycle) - for diesel and spark ignition engines fuelled with gaseous fuels (compressed natural gas and liquefied petroleum gas).

In the ESC test the following unit emissions are determined $[3,4,8]$ :

- carbon monoxide $\mathrm{CO}$,

- hydrocarbons $\mathrm{HC}$,

- nitric oxides $\mathrm{NO}_{\mathrm{x}}$ : nitrogen monoxide $\mathrm{NO}$ nitrogen dioxide $\mathrm{NO}_{2}$, reduced to nitrogen oxide,

- particulate matter PM (for diesel engines).

In the ETC test the following unit emissions are determined $[3,4,8]$ :

- carbon monoxide $\mathrm{CO}$,

- non-methane hydrocarbons NMHC - for spark ignition engines fuelled with gaseous fuels and for diesel engines on the Euro III-Euro V level,

- methane $\mathrm{CH}_{4}$ - for spark ignition engines fuelled with gaseous fuels (for LPG only on the Euro VI level),

- hydrocarbons - for diesel engines on the Euro VI level,

- nitric oxides $\mathrm{NO}_{\mathrm{x}}$,

- particulate matter PM - for diesel engines and spark ignition engines fuelled with gaseous fuels on the EURO V and Euro VI levels.

In non European states different testing procedures are applied but the idea and system of the criteria related quantities lying behind them are similar to those use in Europe $[3,4,8]$.

Meeting by a combustion engine of all the required emission limits leads to a classification and qualification of an engine into an appropriate environmental class, yet the mere results of the tests do not allow a general synthetic environmental assessment of the engine. As of now, there are no formalized methods of synthetic environmental assessment of combustion engines in terms of their toxic emissions. This paper attempts to develop a synthetic method of an environmental assessment of combustion engines in terms of their toxic emissions. Methods of evaluation of the air quality $[7,12,13]$ and systems of emission related charges from combustion engines have thus been analyzed $[6,11]$.

\section{The usefulness of the methods of air quality evaluations in the synthetic assessment of the emissions from combustion engines}

The quality of the atmospheric air is evaluated based on the concentrations of toxic compounds in the air also called, following the German language literature - 'immisions' [10].

The most frequent immisions analyzed in order to assess the air quality are $[7,12,13]$ : sulfur dioxide $\mathrm{SO}_{2}$ and the fractions of PM10 and PM2.5. Interchangeably, in different systems these quantities are supplemented with the emission of ozone $\mathrm{O}_{3}$, carbon monoxide $\mathrm{CO}$, nitrogen dioxide $\mathrm{NO}_{2}$ and benzene $\mathrm{C}_{6} \mathrm{H}_{6}[7,12,13]$. For the evaluation of the air quality most frequently the combinations of the above immisions are used, averaged in the periods of $1 \mathrm{~h}, 8 \mathrm{~h}$ and $24 \mathrm{~h}[7,12,13]$.

In the US EPA „Air quality index reporting - final rule" [13] for the evaluation of the air classified according to the się z testu UDC (Urban Driving Cycle), symulującego jazdę w miastach oraz EUDC (Extra Urban Driving Cycle) do symulacji ruchu poza miastami $[3,4,8]$.

Emisję jednostkową w badaniach homologacyjnych wyznacza się jako wartość średnią w testach realizowanych na hamowni silnikowej. Zgodnie z regulaminem nr 49 EKG obecne limity emisji jednostkowej zanieczyszczeń są oznaczane Euro II-Euro IV (w przyszłości Euro V i Euro VI) $[3,4,8]$. Badania od Euro III są przeprowadzane $\mathrm{w}$ testach $[3,4,8]$ :

- statycznym ESC (European Steady Cycle) $)^{2)}$ - dla silników o zapłonie samoczynnym,

- dynamicznym ETC (European Transient Cycle) - dla silników o zapłonie samoczynnym i silników o zapłonie iskrowym zasilanych paliwami gazowymi (gaz ziemny $\mathrm{i}$ skroplony gaz ropopochodny).

W teście ESC wyznacza się emisje jednostkowe [3, 4, 8]:

- tlenku węgla CO,

- węglowodorów HC,

- tlenków azotu $\mathrm{NO}_{\mathrm{x}}$ : tlenku azotu NO i dwutlenku azotu $\mathrm{NO}_{2}$, sprowadzonych do tlenku azotu,

- cząstek stałych PM - dla silników o zapłonie samoczynnym.

W teście ETC wyznacza się emisje jednostkowe [3, 4, 8]: - tlenku węgla $\mathrm{CO}$,

- niemetalowych węglowodorów NMHC - dla silników o zapłonie iskrowym zasilanych paliwami gazowymi oraz dla silników o zapłonie samoczynnym na poziomie Euro III-Euro V,

- metanu $\mathrm{CH}_{4}$ - dla silników o zapłonie iskrowym zasilanych paliwami gazowymi (dla skroplonego gazu ropopochodnego tylko na poziomie Euro VI),

- węglowodorów - dla silników o zapłonie samoczynnym na poziomie Euro VI,

- tlenków azotu $\mathrm{NO}_{\mathrm{x}}$,

- cząstek stałych PM - dla silników o zapłonie samoczynnym oraz dla silników o zapłonie iskrowym zasilanych paliwami gazowymi na poziomach Euro V i Euro VI.

W państwach pozaeuropejskich stosuje się inne procedury badawcze, jednak sama idea i systematyka wielkości kryterialnych do oceny emisji zanieczyszczeń z silników spalinowych są podobne do stosowanych w Europie [3, 4, 8].

Spełnienie przez silnik spalinowy wszystkich wymagań limitów wielkości charakteryzujących emisje zanieczyszczeń umożliwia zakwalifikowanie silnika do właściwej kategorii ekologicznej, jednak same wyniki badań nie umożliwiają ogólnej syntetycznej oceny ekologicznej silnika. Dotychczas nie ma sformalizowanych metod syntetycznej oceny ekologicznej silników spalinowych ze względu na emisję zanieczyszczeń. W niniejszym artykule podjęto próbę opracowania metody syntetycznej oceny ekologicznej silników spalinowych ze względu na emisję zanieczyszczeń.

\footnotetext{
2) W niektórych publikacjach jest spotykane określenie testu ESC w języku angielskim European Stationary Cycle, wynikające z powszechnej nieznajomości sensu pojęcia stacjonarności, błędnie opisywane w języku polskim jako ,europejski test stacjonarny”, zamiast - właściwie - „europejski test statyczny".
} 
index within the range of $0-500$ the immisions of ozone, fractions of PM10 and PM2.5, carbon monoxide and carbon dioxide are used.

In the system of Regional Monitoring Agency of the Atmosphere of the Agglomeration of Gdańsk (Agencja Monitoringu Regionalnego Atmosfery Aglomeracji Gdańskiej) for the determining of the general and ozone indexes the immisions of the following are used: nitrogen dioxide, sulfur dioxide, PM10 and benzene (Tab. 1) [7]. The quality of the air is evaluated based on the highest index value for the substances under consideration.
Przeanalizowano w związku z tym metody oceny jakości powietrza atmosferycznego $[7,12,13]$ i systemy opłat za emisje zanieczyszczeń z silników spalinowych $[6,11]$.

\section{Przydatność metod oceny jakości powietrza atmosferycznego do syntetycznej oceny emisji zanieczyszczeń z silników spalinowych}

Jakość powietrza atmosferycznego ocenia się na podstawie stężeń zanieczyszczeń w powietrzu atmosferycznym, zwanych - wzorem nomenklatury stosowanej w literaturze niemieckojęzycznej - imisjami [10].

Table 1. Data needed for the determining of the general and ozone indexes for the evaluation of the air based on the toxic compound concentrations Tabela 1. Dane do wyznaczania indeksu ogólnego i indeksu ozonowego do oceny jakości powietrza na podstawie stężén zanieczyszczén w powietrzu atmosferycznym

\begin{tabular}{|c|c|c|c|c|c|}
\hline $\mathrm{NO}_{2}$ & $\mathrm{SO}_{2}$ & $\mathrm{PM} 10$ & $\mathrm{C}_{6} \mathrm{H}_{6}$ & $\mathrm{O}_{3}$ & Indexes: general and ozone/indeksy: ogólny $i$ ozonowy \\
\hline $0-30$ & $0-40$ & $0-20$ & $0-1$ & $0-40$ & Very good (1)/bardzo dobry \\
\hline $30-85$ & $40-120$ & $20-80$ & $1-4$ & $40-80$ & Good (2)/dobry \\
\hline $85-110$ & $120-160$ & $80-100$ & $4-6$ & $80-120$ & Fair (3)/zadowalajacy \\
\hline $110-165$ & $160-250$ & $100-160$ & $6-12$ & $120-180$ & Satisfactory (4)/dostateczny \\
\hline $165-275$ & $250-400$ & $160-240$ & $12-20$ & $180-240$ & Bad (5)/niedobry \\
\hline $275-400$ & $400-500$ & $240-280$ & $20-30$ & $>240$ & Very bad (6)/bardzo niedobry \\
\hline
\end{tabular}

The methods of evaluation of the quality of the air unfortunately do not constitute a good example to be used in the synthetic assessment of the emissions from combustion engines. Far better are systems of charges for the emissions introduced to the environment.

\section{The evaluation of the usefulness of the systems of charges for the emissions from combustion engines}

Out of the systems of charges two have been selected:

- Announcement of the Minister of Environment dated 20.09.2007 on the rates for environment pollution in 2008 [11],

- proposal of the Directive of the European Parliament and the European Council on the promotion of ecologically clean and energy efficient vehicles in road transportation - proposal dated 19.12.2007-KOM(2007)817 final version - 2005/0283 (COD) [6]

For the analysis of the material contained in the said systems two assumptions have been adopted:

1. Euro exchange rate as of 27 January 2009 r.: 1 EUR = $=4.3214$ PLN .

2. Average mass share of cyclic hydrocarbons and their derivatives in the fuels amounted to 0.7 .

Table 2 presents the unit charges for the emission of toxic compounds from road vehicles as per the Announcement of the Minister of Environment, and Table 3 unit charges for the emission of toxic compounds from road vehicles as per the proposal of the Directive of the European Parliament and the European Council (Fig. 1).

In the presented systems of charges there are two visible differences. The first difference is that in the system compli-
Najczęściej do oceny jakości powietrza atmosferycznego wykorzystuje się imisje takich substancji, jak [7, 12, 13]: dwutlenek siarki $\mathrm{SO}_{2}$ oraz frakcje pyłów PM10 i PM2,5. Wymiennie w różnych systemach wielkości te są uzupełnione imisjami ozonu $\mathrm{O}_{3}$, tlenku węgla $\mathrm{CO}$, dwutlenku azotu $\mathrm{NO}_{2} \mathrm{i}$ benzenu $\mathrm{C}_{6} \mathrm{H}_{6}[7,12,13]$. Do oceny jakości powietrza atmosferycznego wykorzystuje się zazwyczaj kombinacje imisji wymienionych substancji, uśrednianych w okresach $1 \mathrm{~h}, 8 \mathrm{~h}$ i $24 \mathrm{~h}[7,12,13]$.

W opracowaniu US EPA pt. „Air quality index reporting - final rule" [13] do oceny jakości powietrza atmosferycznego, klasyfikowanej według indeksu zawartego w granicach 0-500, wykorzystuje się imisje: ozonu, frakcji pyłów PM10 i PM2,5, tlenku węgla i dwutlenku siarki.

W systemie Agencji Monitoringu Regionalnego Atmosfery Aglomeracji Gdańskiej do wyznaczania indeksu ogólnego i indeksu ozonowego wykorzystuje się imisje: dwutlenku azotu, dwutlenku siarki, pyłu zawieszonego PM10 i benzenu (tab. 1) [7]. Jakość powietrza jest oceniana na podstawie największej wartości indeksu dla rozważanych substancji.

Metody oceny jakości powietrza atmosferycznego nie stanowią, niestety, dobrego wzorca do wykorzystania $\mathrm{w}$ celu syntetycznej oceny emisji zanieczyszczeń z silników spalinowych. Znacznie lepsze możliwości istnieją dzięki wykorzystaniu systemów opłat za emisję zanieczyszczeń wprowadzanych do środowiska.

\section{Ocena przydatności systemów opłat za emisje zanieczyszczeń do syntetycznej oceny emisji zanieczyszczeń z silników spalinowych}

Spośród systemów opłat za emisje zanieczyszczeń wybrano dwa: 
Table 2. Unit charges for the emission of toxic compounds from road vehicles as per the Announcement of the Minister of Environment

Tabela 2. Opłaty jednostkowe za emisję zanieczyszczeń z pojazdów drogowych zgodnie z Obwieszczeniem Ministra Środowiska

\begin{tabular}{|c|c|c|c|c|c|c|}
\hline $\mathrm{CO}$ & $\mathrm{HC}$ & $\mathrm{NO}_{\mathrm{x}}$ & PM & $\mathrm{CO}_{2}$ & $\mathrm{HC}_{\mathrm{al}}$ & $\mathrm{HC}_{\mathrm{ar}}$ \\
\hline \multicolumn{7}{|c|}{$[\mathrm{PLN} / \mathrm{kg}]$} \\
\hline 0.11 & 0.43 & 0.43 & 0.29 & 0.00022 & 0.11 & 1.17 \\
\hline \multicolumn{7}{|c|}{ [EUR/kg] } \\
\hline $2.55 \mathrm{E}-02$ & $9.95 \mathrm{E}-02$ & $9.95 \mathrm{E}-02$ & $6.71 \mathrm{E}-02$ & 5.09E-05 & $2.55 \mathrm{E}-02$ & $2.71 \mathrm{E}-01$ \\
\hline
\end{tabular}

Table 3. Unit charges for the emission of toxic compounds from road vehicles as per the proposal of the Directive of the European Parliament and the European Council

Tabela 3. Opłaty jednostkowe za emisję zanieczyszczeń z pojazdów drogowych zgodnie z propozycją Dyrektywy Parlamentu Europejskiego i Rady

\begin{tabular}{|c|c|c|c|c|}
\hline $\mathrm{CO}$ & NMHC & $\mathrm{NO}_{x}$ & PM & $\mathrm{CO}_{2}$ \\
\hline \multicolumn{5}{|c|}{ [EUR/kg] } \\
\hline 0 & 1 & 4.4 & 87 & 0.02 \\
\hline
\end{tabular}

ant with the proposal of the Directive of the European Parliament and the European Council no charges for the carbon monoxide emitted to the atmosphere are included. This means that the local threat of carbon monoxide is not taken into account and only relevant global threats are considered. The other difference is the charge for hydrocarbons in the system compliant with the Announcement of the Minister of Environment and non-methane hydrocarbons in the system compliant with the proposal of the Directive of the European Parliament and the European Council. This difference is not overly significant for two reasons: 1) methane is not very harmful to the health of living organisms, though it is listed a gas facilitating the greenhouse effect, 2) there is relatively low amount of methane in the exhaust gases of engines fuelled with liquid fuels but there is a high amount of this gas in the exhaust of natural gas fuelled vehicles. Hence, further in this paper we will not take the difference between hydrocarbons and non-methane hydrocarbons into account and refer to them as simply hydrocarbons.

The systems of rates for the emissions from combustion engines enable a synthetic assessment of the harmfulness of the exhaust emissions to the environment. As an example of the application of the method of assessment of the harmfulness of the exhaust emissions a comparison was carried out of the emissions from a EURO IV diesel engine-PD-EURO IV and a diesel engine fuelled with bioethanol E95 - Scania DC9 E02 270-E95.

Figures 2-5 present the limits of unit emissions of the toxic compounds on the EURO IV level [3-5, 8] and the unit emissions of the engine fueled with bioethanol-Scania DC9 E02 270 in the stationary ESC and transient ETC cycles [5].

The value of the unit emission of carbon monoxide in the ESC and ETC tests (equals zero) needs a comment. This value results from the accuracy level of determining of this quantity i.e. in the homologation tests the unit emission of carbon monoxide is determined with the accuracy level to a single decimal place, which means that the determined values of the unit emission are lower than $0.05 \mathrm{~g} /(\mathrm{kW} \cdot \mathrm{h})$.
- Obwieszczenie Ministra Środowiska z dnia 20.09.2007 r. W sprawie stawek opłat za korzystanie ze środowiska w 2008 r. [11],

- propozycję Dyrektywy Parlamentu Europejskiego i Rady w sprawie promowania ekologicznie czystych i energooszczędnych pojazdów w transporcie drogowym propozycja z dnia 19.12.2007 r. - KOM(2007)817 wersja ostateczna - 2005/0283 (COD) [6].

Do analizy materiału zawartego w wymienionych systemach przyjęto dwa założenia:

1. Kurs euro na dzień 27 stycznia 2009 r.: 1 euro = 4,3214 PLN.

2. Średni udział masowy węglowodorów łańcuchowych i ich pochodnych w paliwach równy 0,7 .

W tabeli 2 przedstawiono opłaty jednostkowe za emisję zanieczyszczeń z pojazdów drogowych zgodnie z Obwieszczeniem Ministra Środowiska, a w tabeli 3 opłaty jednostkowe za emisję zanieczyszczeń z pojazdów drogowych zgodnie z propozycją Dyrektywy Parlamentu Europejskiego i Rady (rys. 1).

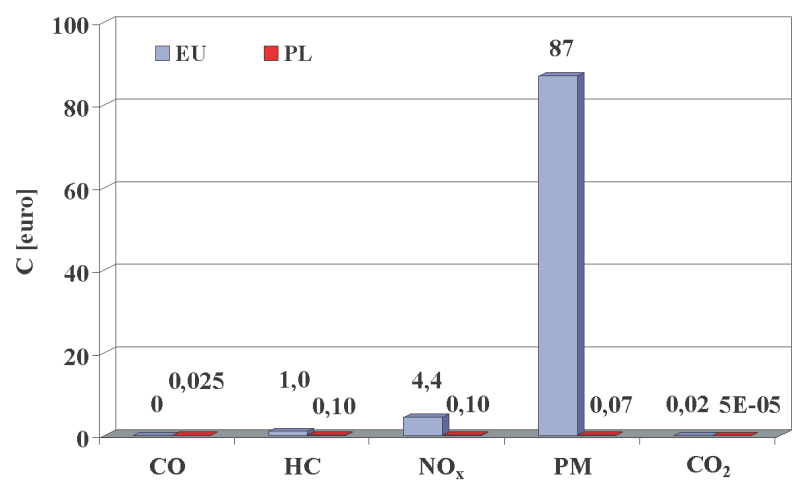

Fig. 1. C Rates for the emissions from combustion engines according to the systems under consideration: The Announcement of the Minister of Environment - PL and the proposal of the Directive of the European Parliament and the European Council - EU

Rys. 1. Stawki opłat C za emisję zanieczyszczeń z silników spalinowych zgodne z rozpatrywanymi systemami: Obwieszczenia Ministra Środowiska-oznaczenie PL i propozycji Dyrektywy Parlamentu Europejskiego $i$ Rady-oznaczenie EU 


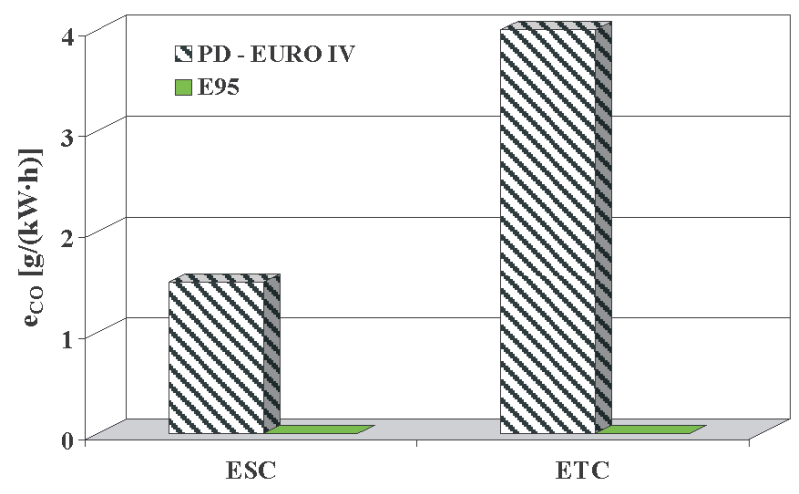

Fig. 2. Unit emission of carbon monoxide $e_{\mathrm{CO}}$ from PD-EURO IV and E95 engine in ESC and ETC

Rys. 2. Emisja jednostkowa tlenku wegla e $e_{C O}$ z silnika PD-EURO IV i z E95 w testach ESC $i$ ETC

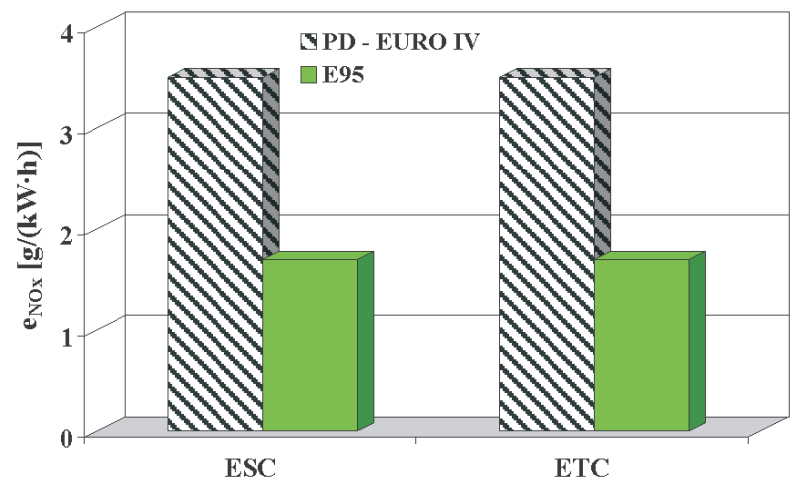

Fig. 4. Unit emission of nitric oxides $\mathrm{e}_{\mathrm{NOx}}$ from PD-EURO IV and $\mathrm{E} 95$ engine in ESC and ETC

Rys. 4. Emisja jednostkowa tlenków azotu $e_{N O x} z$ silnika PD-EURO IV i z E95 w testach ESC $i$ ETC

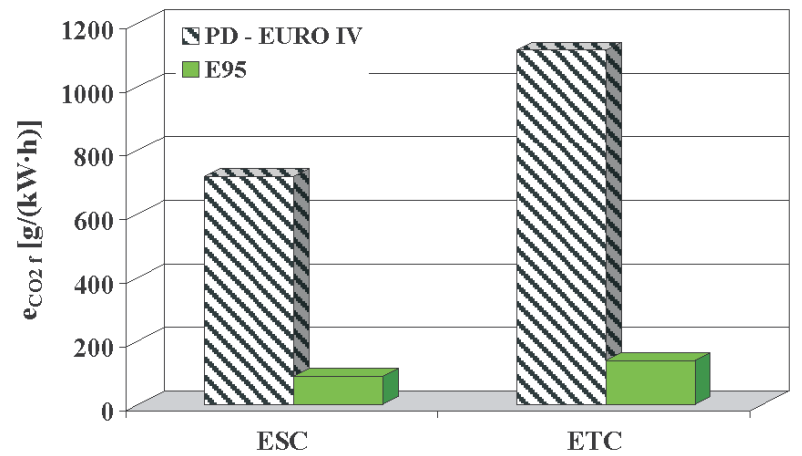

Fig. 6. Unit emission of carbon monoxide (fossil) $\mathrm{e}_{\mathrm{CO2f}}$ from PD-EURO IV and E95 engine in ESC and ETC

Rys. 6. Emisja jednostkowa dwutlenku wegla kopalnego $e_{\mathrm{CO}}$ z silnika PD-EURO IV i z E95 w testach ESC i ETC

The unit emission of carbon monoxide (fossil) has also been compared from these engines in the ETC and ESC, using the test results obtained by the author in collaboration with Environment Canada (Fig. 6).

Based on the emission tests results from the engines under consideration the charge rates for unit emissions $\mathrm{s}_{\mathrm{S}}$, versus

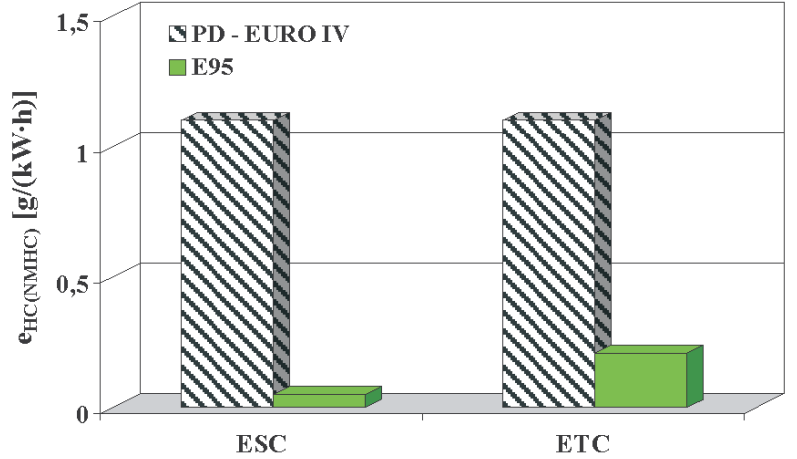

Fig. 3. Unit emission of hydrocarbons $\mathrm{e}_{\mathrm{HC}}$ from PD-EURO IV and $\mathrm{E} 95$ engine in ESC and ETC

Rys. 3. Emisja jednostkowa węglowodorów e $e_{H C} z$ silnika PD-EURO IV i z E95 w testach ESC $i$ ETC

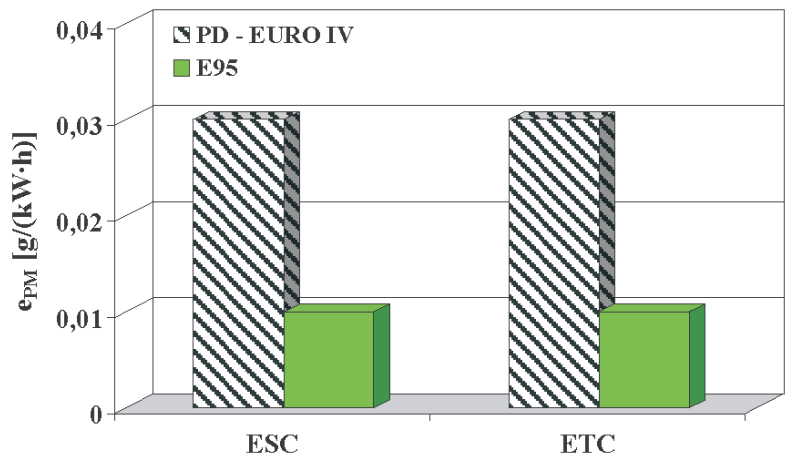

Fig. 5. Unit emission of particulate matter $e_{\mathrm{PM}}$ from PD-EURO IV and E95 engine in ESC and ETC

Rys. 5. Emisja jednostkowa czastek stalych $e_{P M} z$ silnika PD-EURO IV i z E95 w testach ESC $i$ ETC

W przedstawianych systemach opłat są znamienne dwie różnice. Pierwszą jest to, że w systemie zgodnym z propozycją Dyrektywy Parlamentu Europejskiego i Rady nie przewiduje się opłaty za wprowadzanie do środowiska tlenku węgla. Oznacza to, że nie uwzględnia się lokalnej szkodliwości tlenku węgla, rozpatrując jedynie globalne zagrożenie z powodu dwutlenku węgla. Druga różnica to opłata w systemie zgodnym z Obwieszczeniem Ministra Środowiska za węglowodory, a w systemie zgodnym z propozycją Dyrektywy Parlamentu Europejskiego i Rady za niemetalowe węglowodory. Nie jest to różnica szczególnie istotna $\mathrm{z}$ dwóch powodów: 1) metan jest mało groźny dla zdrowia organizmów żywych, choć zalicza się do gazów sprzyjających intensyfikacji zjawiska cieplarnianego $\mathrm{w}$ atmosferze, 2) w spalinach silników zasilanych paliwami ciekłymi jest stosunkowo mało metanu, występuje on natomiast w znaczących ilościach w spalinach silników zasilanych gazem ziemnym. W dalszych rozważaniach niniejszej publikacji nie uwzględnia się zatem różnicy węglowodorów i niemetalowych węglowodorów, traktując te substancje umownie jako węglowodory.

Systemy stawek opłat za emisję zanieczyszczeń silników spalinowych umożliwiają syntetyczną ocenę szkodliwości 
usable engine work (Fig. 7 and 8) have been established:

$$
\mathrm{s}_{\mathrm{S}}=\sum_{\mathrm{i}} \mathrm{C}_{\mathrm{i}} \cdot \mathrm{e}_{\mathrm{i}} / 1000[\mathrm{EUR} /(\mathrm{kW} \cdot \mathrm{h})] \text { or }[\mathrm{PLN} /(\mathrm{kW} \cdot \mathrm{h})]
$$

where: $\mathrm{C}_{i}$ - charge rates for individual substances in $\mathrm{EUR} / \mathrm{kg}$ or PLN $/ \mathrm{kg}, \mathrm{e}_{\mathrm{i}}-$ unit emission of individual substances in $\mathrm{g} /(\mathrm{kW} \cdot \mathrm{h}), \mathrm{i}-$ marks the emitted substance.

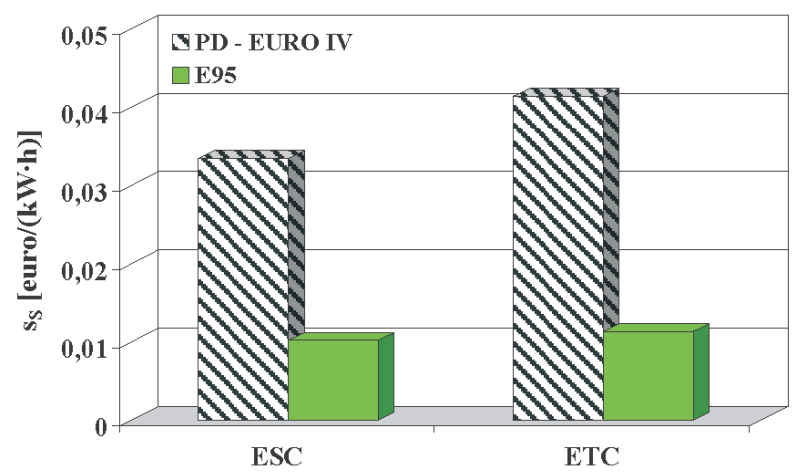

Fig. 7. Unit charges $s_{\mathrm{S}}$ for the emissions from PD-EURO IV and E95 engine in ESC and ETC as per the proposal of the Directive of the European Parliament and the European Council

Rys. 7. Opłaty jednostkowe $s_{S} z$ a emisje zanieczyszczeń z silnika

PD-EURO IV i z E95 w testach ESC i ETC wedtug propozycji Dyrektywy Parlamentu Europejskiego i Rady

Based on the conducted tests we can conclude that the synthetic harmfulness of the emissions from a classic and bioethanol engines differ significantly (Fig. 9). A relative difference between the unit charges for the emissions from PD-EURO IV engine and the unit charges for the emissions from E95 engine in the ESC and ETC tests as per the proposal of the Directive of the European Parliament and the European Council and the Announcement of the Minister of Environment $\delta\left(\mathrm{s}_{\mathrm{S}}\right)$ is as follows:

$$
\delta\left(\mathrm{s}_{\mathrm{S}}\right)=\frac{\mathrm{s}_{\mathrm{S}}(\mathrm{PD}-\mathrm{EUROIV})-\mathrm{s}_{\mathrm{S}}(\mathrm{E} 95)}{\mathrm{s}_{\mathrm{S}}(\mathrm{PD} \text { EURO IV })}
$$

where: $\mathrm{s}_{\mathrm{s}}(\mathrm{PD}-\mathrm{EURO}$ IV) - the charge for the PD-EURO IV engine, $\mathrm{s}_{\mathrm{s}}(\mathrm{E} 95)$ - the charge for the E95 engine.

On average this difference amounts to approximately $70 \%$.

Much higher are the charges for environment pollution as per the proposal of the Directive of the European Parliament and the European Council as opposed to the Announcement of the Minister of Environment. Figure 10 shows a relative difference in unit charges for the emission of toxic substances from the PD-EURO IV engine and E95 engine in the ESC and ETC tests as per the proposal of the Directive of the European Parliament and the European Council as opposed to the unit charges as per the Announcement of the Minister of Environment $\delta_{\mathrm{EU} / \mathrm{PL}}$ : spalin dla środowiska. Jako przykład zastosowania oceny szkodliwości spalin przeprowadzono porównanie szkodliwości emitowanych zanieczyszczeń z silnika o zapłonie samoczynnym kategorii ekologicznej EURO IV - oznaczenie PD-EURO IV i z silnika o zapłonie samoczynnym, zasilanego paliwem bioetanolowym E95 - Scania DC9 E02 270 - oznaczenie E95.

Na rysunkach $2-5$ przedstawiono limity emisji jednostkowej zanieczyszczeń na poziomie EURO IV [3-5, 8] oraz emisję jednostkową zanieczyszczeń z silnika bioetanolowego Scania DC9 E02 270 w testach: statycznym ESC i dynamicznym ETC [5].

Komentarza wymaga wartość emisji jednostkowej tlenku węgla w testach ESC i ETC dla silnika bioetanolowego równa zero. Wynika to z dokładności wyznaczania tej wielkości, mianowicie $\mathrm{w}$ badaniach homologacyjnych wyznacza się emisję jednostkową tlenku węgla $z$ dokładnością do jednego miejsca po przecinku, co oznacza, że wyznaczone wartości emisji jednostkowej są mniejsze od $0,05 \mathrm{~g} /(\mathrm{kW} \cdot \mathrm{h})$.

Porównano również emisję jednostkową dwutlenku węgla kopalnego z tych silników w testach ETC i ESC, wykorzystując do tego celu wyniki badań wykonanych przez autora we współpracy z Environment Canada (rys. 6).

Na podstawie wyników badań emisji zanieczyszczeń z ocenianych silników wyznaczono wartości opłat jednostkowych za emisje $\mathrm{s}_{\mathrm{s}}$, odniesionych do pracy użytecznej silnika (rys. 7 i 8):

$$
\mathrm{s}_{\mathrm{S}}=\sum_{\mathrm{i}} \mathrm{C}_{\mathrm{i}} \cdot \mathrm{e}_{\mathrm{i}} / 1000[\mathrm{euro} /(\mathrm{kW} \cdot \mathrm{h})] \mathrm{lub}[\mathrm{PLN} /(\mathrm{kW} \cdot \mathrm{h})]
$$

gdzie: $\mathrm{C}_{\mathrm{i}}$ - stawki opłat za poszczególne substancje w euro/kg lub PLN/kg, $e_{i}-$ emisja jednostkowa poszczególnych substancji w $\mathrm{g} /(\mathrm{kW} \cdot \mathrm{h}), \mathrm{i}$ - oznaczenie emitowanej substancji.

Na podstawie przeprowadzonych badań można stwierdzić, że bardzo znacznie różni się syntetyczna szkodliwość substancji emitowanych z silnika klasycznego i z bioetanolowego - rys. 9. Względna różnica opłat jednostkowych za emisję zanieczyszczeń z silnika PD-EURO IV w stosunku do opłat jednostkowych za emisję zanieczyszczeń z silnika E95 w testach ESC i ETC według propozycji Dyrektywy Parlamentu Europejskiego i Rady oraz Obwieszczenia Ministra Środowiska $\delta\left(\mathrm{s}_{\mathrm{S}}\right)$ wynosi:

$$
\delta\left(\mathrm{s}_{\mathrm{S}}\right)=\frac{\mathrm{s}_{\mathrm{S}}(\mathrm{PD}-\mathrm{EUROIV})-\mathrm{s}_{\mathrm{S}}(\mathrm{E} 95)}{\mathrm{s}_{\mathrm{S}}(\text { PD EURO IV })}
$$

gdzie: $\mathrm{s}_{\mathrm{s}}(\mathrm{PD}-\mathrm{EURO}$ IV) - opłata dla silnika PD-EURO IV, $\mathrm{s}_{\mathrm{S}}$ (E95) - opłata dla silnika E95.

Przeciętnie różnica ta wynosi około $70 \%$.

Dużo większe są opłaty za zanieczyszczania środowiska zgodnie z propozycją Dyrektywy Parlamentu Europejskiego i Rady w stosunku do Obwieszczenia Ministra Środowiska. Na rysunku 10 przedstawiono względną różnicę opłat jednostkowych za emisję zanieczyszczeń z silników 

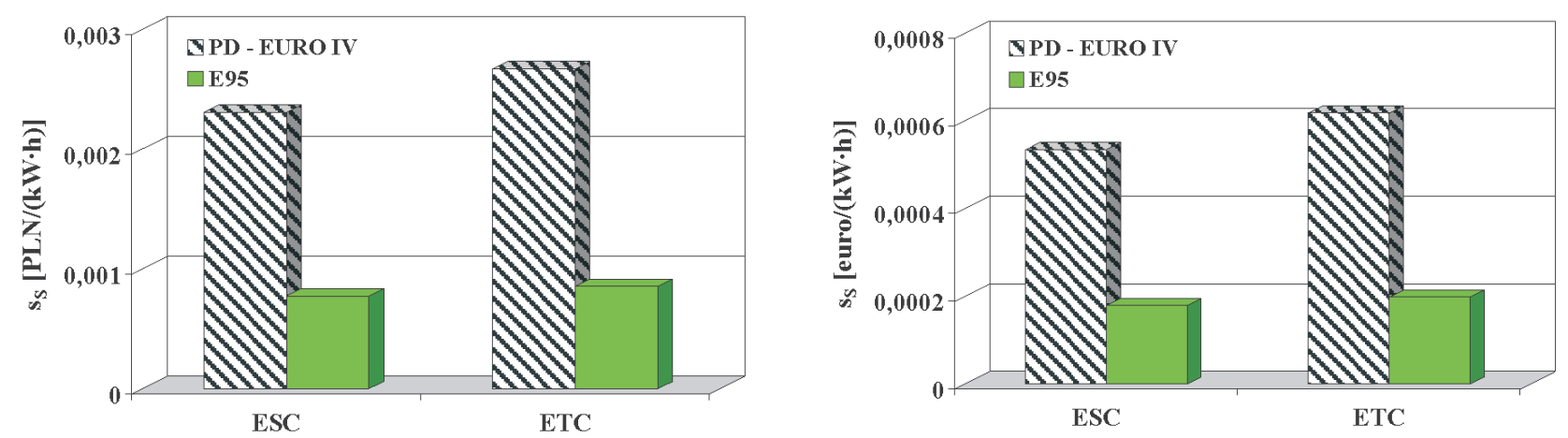

Fig. 8. Unit charges $\mathrm{s}_{\mathrm{S}}$ for the emissions from PD-EURO IV and E95 engine in ESC and ETC as per the Announcement of the Minister of Environment (in PLN and EUR)

Rys. 8. Optaty jednostkowe $s_{S}$ za emisje zanieczyszczeń z silnika PD-EURO IV i z E95 w testach ESC i ETC wedlug Obwieszczenia Ministra Środowiska (w PLN $i$ w euro)

$$
\delta_{\mathrm{EU} / \mathrm{PL}}=\frac{\mathrm{s}_{\mathrm{S}}(\mathrm{EU})-\mathrm{s}_{\mathrm{S}}(\mathrm{PL})}{\mathrm{s}_{\mathrm{S}}(\mathrm{PL})}
$$

where: $\mathrm{s}_{\mathrm{S}}(\mathrm{EU})$ - charge as per the proposal of the Directive of the European Parliament and the European Council, $\mathrm{s}_{\mathrm{S}}(\mathrm{PL})$ - charge as per the Announcement of the Minister of Environment.

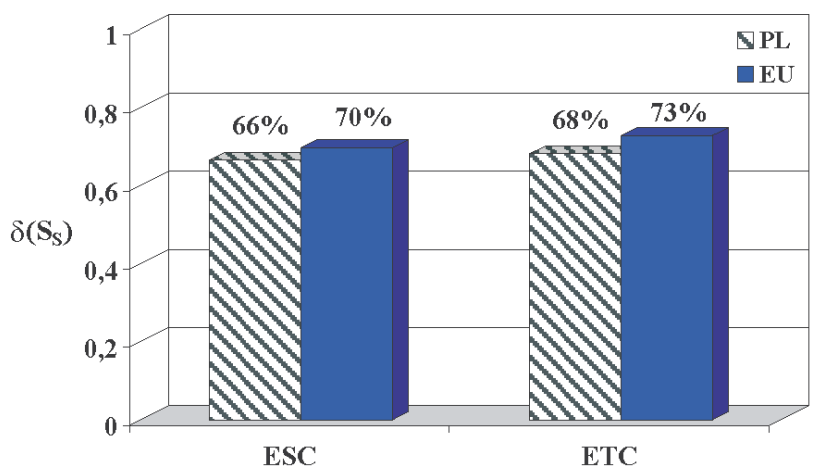

Fig. 9. A relative difference $\delta\left(\mathrm{s}_{\mathrm{s}}\right)$ between the unit charges for the emissions from PD-EURO IV engine and the unit charges for the emissions from E95 engine in the ESC and ETC tests as per the proposal of the Directive of the European Parliament and the European Council and the Announcement of the Minister of Environment

Rys. 9. Względna różnica $\delta\left(s_{S}\right)$ opłat jednostkowych za emisję zanieczyszczeń z silnika PD-EURO IV w stosunku do opłat jednostkowych za emisję zanieczyszczeń z silnika E95 w testach ESC i ETC wedlug propozycji Dyrektywy Parlamentu Europejskiego i Rady oraz Obwieszczenia

$$
\text { Ministra Środowiska }
$$

A relative charge difference as per the proposal of the Directive of the European Parliament and the European Council as opposed to the unit charges as per the Announcement of the Minister of Environment exceeds $6000 \%$ !

The conducted tests confirm that the proposed method of using the system of charges for the emissions introduced into the atmosphere is an efficient way of synthetic assessment of emissions from combustion engines.
PD-EURO IV i z E95 w testach ESC i ETC według propozycji Dyrektywy Parlamentu Europejskiego i Rady w stosunku do opłat jednostkowych za emisję zanieczyszczeń według Obwieszczenia Ministra Środowiska $\delta_{\mathrm{EU} / \mathrm{PL}}$ :

$$
\delta_{\mathrm{EU} / \mathrm{PL}}=\frac{\mathrm{s}_{\mathrm{S}}(\mathrm{EU})-\mathrm{s}_{\mathrm{S}}(\mathrm{PL})}{\mathrm{s}_{\mathrm{S}}(\mathrm{PL})}
$$

gdzie: $\mathrm{s}_{\mathrm{S}}(\mathrm{EU})$ - opłata zgodnie z propozycją Dyrektywy Parlamentu Europejskiego i Rady, $\mathrm{s}_{\mathrm{S}}(\mathrm{PL})$ - opłata zgodnie z Obwieszczeniem Ministra Środowiska.

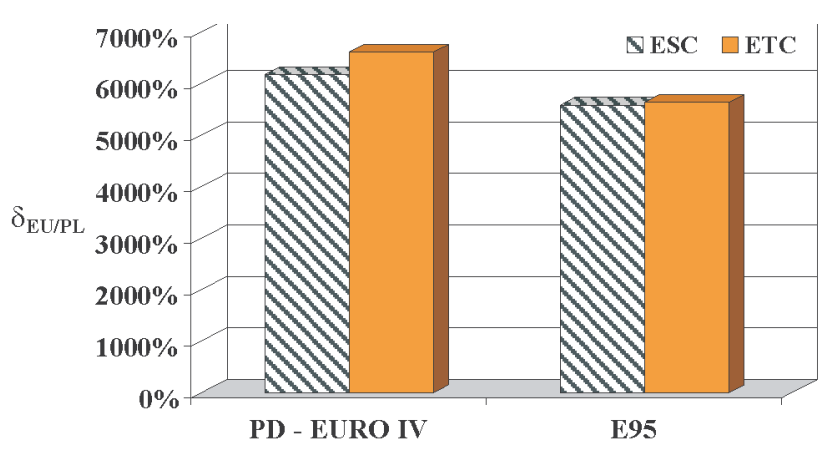

Fig. 10. Relative difference $\delta_{\mathrm{EU} / \mathrm{PL}}$ of the unit charges for the emissions from the PD-EURO IV and E95 engines in the ESC and ETC tests as per the proposal of the Directive of the European Parliament and the European Council as opposed to the unit charges as per the Announcement of the Minister of Environment

Rys. 10. Względna różnica $\delta_{\mathrm{EU} / \mathrm{PL}}$ opłat jednostkowych za emisję zanieczyszczeń z silników PD-EURO IV $i$ z silnika E95 $w$ testach ESC i ETC wedtug propozycji Dyrektywy Parlamentu Europejskiego i Rady w stosunku do opłat jednostkowych za emisję zanieczyszczeń wedtug Obwieszczenia Ministra Środowiska

Względna różnica opłat według propozycji Dyrektywy w stosunku do opłat według Obwieszczenia przekracza $6000 \%$ !

Przeprowadzone badania potwierdzają, że zaproponowana metoda wykorzystania systemów opłat za wprowadzanie zanieczyszczeń do środowiska jest skutecznym sposobem 


\section{Conclusions}

The proposed method of synthetic assessment of emissions from combustion engines constitutes an efficient means for the valuation of the ecological quality of engines. The method of synthetic assessment of the ecological properties of combustion engines is based on the rates of charges for the emissions introduced into the atmosphere. This method refers to the practical valuation of the harmfulness of the individual pollutants. A comparison of two systems: the proposal of the Directive of the European Parliament and the European Council with the Announcement of the Minister of Environment indicates that the experience in the evaluation of the harmfulness of individual pollutants may differ. This, however does not challenge the fact that we should rely on practically verified evaluations of the harmfulness of individual pollutants.

An example of the application of the developed synthetic assessment of the emissions in a bioethanol engine of very low emissions showed that it is a successful method of ecological valuation of combustion engines technical solutions.

Paper reviewed syntetycznej oceny emisji zanieczyszczeń z silników spalinowych.

\section{Podsumowanie}

Zaproponowana metoda syntetycznej oceny emisji zanieczyszczeń z silników spalinowych stanowi skuteczny środek do wartościowania ekologicznej jakości silników. Metodę oceny syntetycznej ekologicznych właściwości silników spalinowych oparto na stawkach opłat za wprowadzanie zanieczyszczeń do środowiska. Sposób taki odwołuje się do wartościowania szkodliwości poszczególnych zanieczyszczeń, wynikającej z praktyki. Porównanie dwóch systemów: propozycji Dyrektywy Parlamentu Europejskiego i Rady oraz Obwieszczenia Ministra Środowiska wskazuje, iż doświadczenia w ocenie szkodliwości poszczególnych zanieczyszczeń mogą się znacznie różnić. Nie podważa to jednak w niczym słuszności oparcia się na weryfikowanych w praktyce ocenach szkodliwości poszczególnych zanieczyszczeń.

Przykład zastosowania opracowanej syntetycznej oceny emisji zanieczyszczeń w stosunku do silnika bioetanolowego o bardzo małej emisji zanieczyszczeń wykazał, że jest to skuteczna metoda ekologicznego wartościowania rozwiązań technicznych silników spalinowych.

\section{Bibliography/Literatura}

[1] Alloway B.I., Ayres D.C.: Chemiczne podstawy skażenia środowiska, Wydawnictwo Naukowe PWN, Warszawa 1999.

[2] Carter W.P.L.: Development of ozone reactivity scales for volatile organic compounds, Journal of the Air and Waste Management Association, Vol. 44, 1994, pp. 881-899.

[3] Chłopek Z.: Modelowanie procesów emisji spalin w warunkach eksploatacji trakcyjnej silników spalinowych, Prace Naukowe. Seria „Mechanika” z. 173, Oficyna Wydawnicza Politechniki Warszawskiej, Warszawa 1999.

[4] Chłopek Z.: Pojazdy samochodowe - ochrona środowiska naturalnego, WKiŁ, Warszawa 2002.

[5] Chłopek Z.: The estimation of the pollutant emission from internal combustion engines supplied with bioethanol fuels, Combustion Engines, No. 2/2008 (133).

Mr. Zdzisław Chłopek, DSc, DEng. - Professor in the Motor Transport Institute in Warsaw.

Dr hab. inż. Zdzistaw Chtopek-profesor w Instytucie Transportu Samochodowego w Warszawie e-mail: moriarty@o2.pl
[6] Dyrektywa Parlamentu Europejskiego i Rady w sprawie promowania ekologicznie czystych i energooszczędnych pojazdów w transporcie drogowym - propozycja $z$ dnia 19.12.2007 r. - KOM(2007)817 wersja ostateczna $-2005 / 0283$ (COD).

[7] http://armaag.gda.pl/indeks_jakosci_powietrza.htm

[8] http://www.dieselnet.com

[9] Juda-Rezler K.: Oddziaływanie zanieczyszczeń powietrza na środowisko, Oficyna Wydawnicza Politechniki Warszawskiej, Warszawa 2000.

[10] Lohmeyer A., Düring I.: Quantifizierung der Feinstaubausbildung im Nahbereich von Straßen, Senatsverwaltung für Stadtentwicklung, Umweltschutz und Technologie, Berlin 2001.

[11] Obwieszczenie Ministra Środowiska z dnia 20.09.2007 r. w sprawie stawek opłat za korzystanie ze środowiska w $2008 \mathrm{r}$.

[12] US EPA - New Jersey Department: 2004 Air quality index summary. http://www.state.nj.us/dep/airmon/aqi04.pdf.

[13] US EPA: Air quality index reporting - final rule. 40 CFR Part 58. Federal Register, vol. 64, no. 149. August 4, 1999.

[14] Sandor R.L., Walsh M.J.: Kyoto or not: Opportunities in carbon trading are here, Environmental Quality Management, Springer 2001. 